\title{
DEVELOPING STUDENTS' VOCABULARY WORKSHEET USING SCIENTIFIC APPROACH ON WRITING DESCRIPTIVE TEXT FOR THE SEVENTH GRADE STUDENTS AT SMP NEGERI 2 BABALAN
}

\author{
AN ARTICLE \\ Submitted in Partial Fulfillment of the Requirements for \\ the Degree of Sarjana Pendidikan
}

\section{AMALIA CHANDRA DEWI}

Registration Number: 2133121003

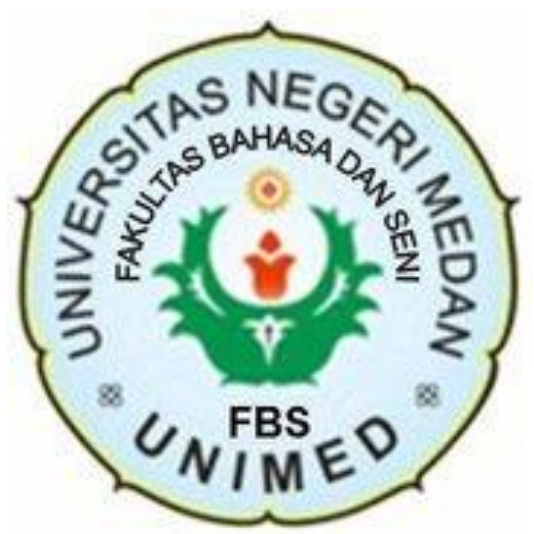

ENGLISH AND LITERATURE DEPARTMENT

FACULTY OF LANGUAGES AND ARTS

UNIVERSITAS NEGERI MEDAN 
ARTIKEL

DEVELOPING STUDENTS' VOCABULARY WORKSHEET USING SCIENTIFIC APPROACH ON WRITING DESCRIPTIVE TEXT FOR THE SEVENTH GRADE STUDENTS AT SMP NEGERI 2 BABALAN

Disusun dan Diajukan oleh:

\section{Amalia Chandra Dewi NIM. 2133121003}

Telah diverifikasi dan dinyatakan memenuhi syarat untuk diunggah pada jurnal online

Medan, Oktober 2020

Menyetujui

Dosen Pembimbing I

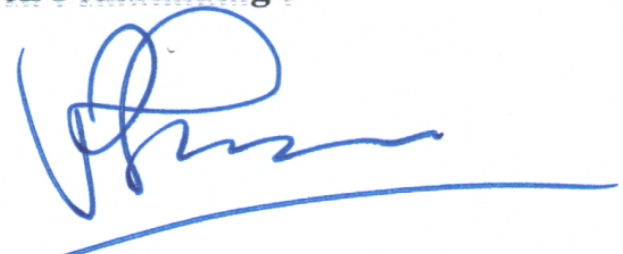

Dr. Rahmad Husein, M.Ed.

NIP. 196206291988031002

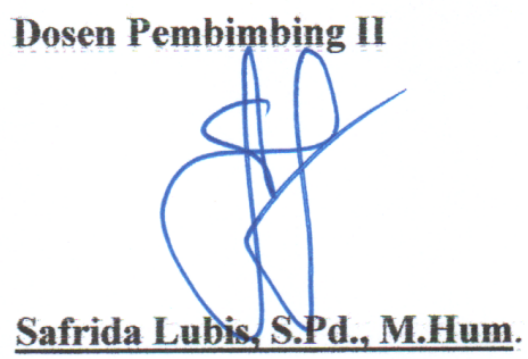

NIP. 197807212007012001

Ka. Program Studi

Pendidikan Bahasa Inggris

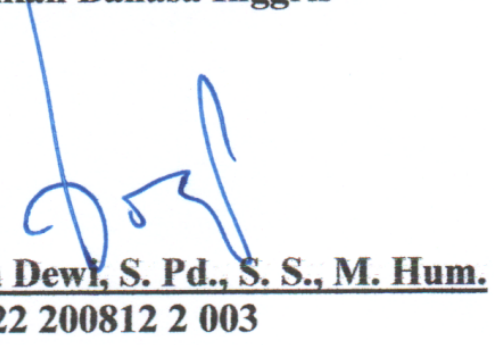

NIP.19800522 2008122003 
DEVELOPING STUDENTS' VOCABULARY WORKSHEET USING

SCIENTIFIC APPROACH ON WRITING DESCRIPTIVE TEXT FOR

THE SEVENTH GRADE STUDENTS AT SMP NEGERI 2 BABALAN

\author{
*Amalia Chandra Dewi \\ **Dr. Rahmad Husein, M.Ed. \\ **Safrida Lubis, S.Pd., M.Hum.
}

\begin{abstract}
S
Dewi, Amalia Chandra. Registration Number: 2133121003. Developing Students' Vocabulary Worksheet using Scientific Approach on Writing Descriptive Text for the Seventh Grade Students at SMP Negeri 2 Babalan. A Thesis. English Education Program, State University of Medan, 2020.
\end{abstract}

The aimed of this study was to develop students' vocabulary worksheet based on scientific approach on writing descriptive text for seventh grade students at SMP Negeri 2 Babalan. This study was conducted by using Research and Development (R\&D) design through six stages; gathering information and data, analyzing data, designing materials, validating by experts, revising, and final product.The subject of the study was grade VII of SMP Negeri 2 Babalan. The instruments of data collection were gathered by administering interview and distributing questionnaire. The study conducted interview to the English teacher and distributing questionnaire to 27 respondents to get the students' needs. The interview and questionnaire results proved that the students need vocabulary worksheet based on scientific approach in writing descriptive which can help students to enrich the vocabulary. The product has been validated by an English lecturer and an English teacher with the average score is 4.6. The product was categorized as "Very good" students' vocabulary worksheet in writing descriptive text. The final product of this study was a set of developed students' vocabulary worksheet in writing descriptive text, it consisted five parts which were adapted from Scientific Approach. Every part has 3-5 tasks that covered the learning needs. It also has key words and the topics that are going to be done by the students in the first page of every part of the worksheet.

Keywords : Vocabulary, Worksheet, Scientific Approach, Research and Development $(R \& D)$, Writing Descriptive Text

\footnotetext{
*Graduate Status

**Lecturer Status
} 


\section{INTRODUCTION}

\section{Background of the Study}

Nunan (2003: 88) states writing as the mental work of inventing ideas, thinking about how to express them, and organizing them into statements and pharagraps that will be clear to a reader. Writing skill is often needed to measure knowledge in most exams, whether they are testing in foreign language abilities or other skills (Harmer: 2004). Wyrick (1987:227) states, “The writer of description creates a word picture of persons, places, objects, and emotions using a careful selection of detail to make an impression on the reader". In writing a descriptive text, the students found some difficulties in vocabulary because they are lack of vocabularies. It can make them difficult in developing their ideas related to their topic.

In addition, vocabulary is the essential part in writing descriptive text. Therefoe, the students will not be able to write if they do not know vocabularies. It relates to Natio (2011) stated that vocabulary learning is an essential part in foreign language learning as the meanings of new words are very often emphasized, whether in books or in classroom. Based on the current research, teaching vocabulary may be problematic because many teachers are not confident about best practice in vocabulary teaching and at times don't know where to begin to form an instructional emphasis on word learning (Berne \& Blachowicz, 2008). In making English learning meaningfully, worksheet is needed. Triantoro (2009) states that students' worksheet is a student guidance to conduct investigation or problem solving.

Based on preliminary data found at SMP Negeri 2 Babalan, it was known that the students have lack of vocabulary especially in writing descriptive text. It also found that the students are lack attractive in the teaching and learning process while the school has implemented curricullum 2013 that uses scientific approach in teaching and learning process. By this approach, the students must be able to develop thinking process through looking for, guessing, and logically. In addition, the preliminary data showed that the teacher did not use worksheet in the classroom. She usually used only a textbook got from the government that was entitled "When English Rings a Bell" to support the teaching learning process. 
Therefore, the researcher conduct the research to develop the appropriate students' vocabulary worksheet on writing descriptive text using Scientific Approach for the seventh grade students at SMP Negeri 2 Babalan.

\section{REVIEW OF LITERATURE}

\section{Writing}

Writing is one of language skills which should be mastered by the students. In writing, there will be product which is written form since the students will deliver the ideas, thoughts, and experiences. Therefore, the students should be able to write well in order to express their feeling, need, and desire in a understandable written form.

Nunan (2003: 88) states writing as the mental work of inventing ideas, thinking about how to express them, and organizing them into statements and pharagraps that will be clear to a reader.

Writing is not easy to do, because before someone writes in a piece of paper, they have to think the appropriate terms which is suitable and understandable. Writing skill is often needed to measure knowledge in most exams, whether they are testing in foreign language abilities or other skills (Harmer: 2004).

Fairbairn and Winch (2011:32) says that writing is a process of transferring ideas which requires appropriate words selection before finally putting them together in a written or printed.

\section{Descriptive Text}

Knapp and Watkins (2005:95) state "the genres of describing are one of the fundamental functions of any language system and one of the first skills emergent language users learn to control". They also state that "descriptions enable the categorization or classification of an almost infinite range of experiences, observations and interaction into a system that orders them either objectively or subjectively, depending on the learning area or intent of the writer".

The social function of descriptive text is primarily to describe a person, place, or thing in such a way that a picture is formed the reader's mind. Capturing 
an event through descriptive writing involves paying close attention to the details by using all your five senses.

According to Knapp and Watkins (2005:100-106), the generic structure of descriptive text is divided into two, they are: identification and description.

According to Knapp and Watkins (2005:98-99) states that grammatical features of descriptive such as; (1) Present Tense, (2) Relational Verbs, (3) Action Verbs, (4) Mental Verbs, (5) Adjectives, (6) Adverbial Phrases.

\section{Vocabulary Skill}

Vocabulary can be defined as " words we must know to communicate effectively; words in speaking (expressive vocabulary) and words in listening (receptive vocabulary)" (Neuman\&Dwyer, 2009, p. 385). Hornby (1995) defines vocabulary as "the total number of words in a language; vocabulary is a list of words with their meanings".

Diamond and Gutlohn (2006) in www.readingrockets.org/article state that vocabulary is the knowledge of words and word meanings." From the definitions above, it can be concluded that vocabulary is the total number of words that are needed to communicate ideas and express the speakers' meaning. That is the reason why it is important to learn vocabulary.

\section{Students' Worksheet}

Triantoro (2009) states that students' worksheet is a student guidance to conduct investigation or problem solving. Sutiasih (2009) states student worksheet is a series of tasks laid out in the form of questions. By answering these questions, students are able to master the materials they studied. Lidyawati (2009) states student worksheet is a series of tasks with questions that make students in working on and get it done. It can be concluded that student worksheet contain several aspect such as title, basic competence, allocation time, brief information instructions, task to perform and the report to make. 


\section{Scientific Approach}

Kemdikbud (2014) states that scientific approach refers to the investigation techniques on some phenomena to get a new knowledge or doing correction and integrating the previous knowledge. So, generally, scientific approach contains a series of activities of collecting data from observing, experimenting, processing the information, analyzing and then formulating and examining the hypotheses.

Kemendikbud (2013) and Hosnan (2014) state that there are five steps of applying scientific approach in teaching learning process. They are observing, questioning, experimenting, associating and communicating.

\section{RESEARCH METHODOLOGY}

This research was conducted by using educational Research and Development (R \& D) by Borg and Gall (2003). This sudy was conducted at SMP Negeri 2 Babalan which is located in Jl. Pendidikan P.Berandan, Kecamatan Babalan, Kabupaten Langkat. The subject of this study is the grade VII students of SMP Negeri 2 Babalan. The instruments of data collection were gathered by administring interview and distributing questionnaire. The study conducted interview to the English teacher and distributing questionnaire to 27 respondents to get the students' needs. In addition, the qualitative and quantitative research were conducted to analyze the data.

\section{RESEARCH FINDING AND DISCUSSION}

\section{Research Findings}

The worksheet was developed after the researcher found that the target needs and the learning needs of the students. The students' preferences were shown by the highest percentage of the students' answer in the need analysis questionnaires. The worksheet then was written in accordance to the highest percentage of the target needs and learning needs. The course grid was written as guideline for developing the worksheet. The researcher wrote five parts. It covered a number of elements which are topic, core competences, basic 
competence, language focus and activities. Language focus consisted of two sub elements that are vocabulary and grammar.

The mean value from all aspects was 4.4. It could be concluded that the worksheet was categorized as "Very Good" since the position of the mean value was in the interval $4.20 \leq x \leq 5$.

\section{Discussion}

As product-based research, this research aims to develop students' writing worksheet for descriptive text that was appropriate for the seventh grade students at SMP Negeri 2 Babalan.

This students' worksheet was developed based on scientific approach for the English teacher in teaching writing descriptive text at SMP Negeri 2 Babalan. The descriptive text will be explained clearly in this worksheet. The activities in this worksheet are expected to make students be more understand about descriptive text and to enrich the students' vocabulary. This worksheet consists of 5 chapters: Observing, Questioning, Experimenting, Associating and Communicating. Every chapter has 3-5 tasks that cover learning needs

Based on the research finding regarding to the target needs and learning needs of the students and the result of the expert judgment, the students' vocabulary worksheet in writing descriptive text developed by using scientific approach in this research was considered appropriate to be used in studying writing descriptive text for the seventh grade students of SMP Negeri 2 Babalan. As the result from the validators, the average evaluation from all aspects was 4.4. It could be concluded that the worksheet was categorized as "Very Good". 


\title{
CONCLUSIONS AND SUGGESTIONS
}

\author{
Conclusions
}

After conducting the need analysis, the course grid was written based on the syllabus in curriculum 2013 and the students' preferences about target need and learning need. After writing the course grid, the first draft of the material was written. The material was written under the five stages of scientific approach: observing, questioning, experimenting, associating, ad communicating. Then the worksheet was validated by the experts. In conclusion, based on the experts' evaluation, the developed worksheet using Scientific Approach was appropriate to be used by the seventh grade students of SMP Negeri 2 Babalan.

\section{Suggestion}

1. For the teacher should find an appropriate students' worksheet in improving their skill and motivating them in learning English.

2. For the students, they can use the worksheet to evaluate their ability in mastering vocabulary on writing descriptive text.

\section{REFERENCES}

Alqahtani, M. (2015). The Importance of Vocabulary in Language Learning and How to be Taught, 3(3): 21-34

Baturkmen, H. (2010). Developing Courses in English for Specific Purpose. New York: Palgrave Macmillan

Belawati, T. (2007). Pegembangan Bahan Ajar. Jakarta: Universitas Terbuka

Berne \& Blachowicz. (2008). What Reading Teachers Say About Vocabulary Instruction: Voices from the Classroom. The Reading Teacher, 62(4), 314323

Borg \& Gall. (2003). Research and Development in Education. Cambridge: Cambridge University Press 
Darusman. (2008). Penggunaan Media Belajar. Jakarta: Ditjen Dikti Depdiknas

Fairbairn \& Winch. (2011). Reading, Writing and Reasoning: a guidance for students. United Kingdom: Open University Press

Fulwiler, T. (2002). College Writing: a Personal Approach to Academic Writing. Portsmouth, NH: Boynton/Cook

Harianti. WY. (2018). Developing English Materials Using Scientific Approach for Eleventh Graders of Senior High School, 6(2)

Harmer, J. (2004). How to Teach Writing: Effective Sentence, Paragraph, and Essay. New York: Longman

Hosnan, M. (2014). Pendekatan Saintifik dan Kontekstual dalam Pembelajaran Abad 21. Bogor: Ghalia Indonesia

Hutchinson \& Waters. (1987). English for Specific Purposes: A Learner-Centered Approach. New York: Cambridge University Press

Hyland, K. (2003). Second Language Writing. New York: Cambridge University Press

Ikhsan \& Handayani (2016). ISELT. The Development Students' Worksheet Using Scientific Approach on Curriculum Materials, 74-84

Istiqomah, N. (2015). Teacher's Attitude toward the Implementation of ScientificApproach of Curriculum 2013 to teach English (A Case Study of the Seventh Grade Class of Junior High Schools in Surakarta in the Academic Year of 2013/2014). Surakarta: Universitas Sebelas Maret

Juzwiak, C. (2009). Pedagogies of Visibility: The Full E-Mersion and Beyond, 145: 79-94

Kemdikbud. (2013). Kompetensi Dasar Sekolah Menengah Pertama (SMP) / Madrasah Tsanawiyah (MTs). Jakarta

Kemdikbud. (2013). Konsep Pendekatan Scientific. Jakarta

Kemdikbud. (2013). Modul Pelatihan Implementasi Kurikulum 2013. Jakarta: Badan Pengembangan Sumber Daya Manusia Pendidikan dan Kebudayaan

Kemdikbud. (2013). Peraturan Menteri Pendidikan dan Kebudayaan nomor 81 a Tahun 2013 tentang Implementasi Kurikulum 2013. Jakarta: Kemdikbud

Khasanah, I. N. (2015). The Implementation of 2013 Curriculum by the English Teacher and Its Barriers. Semarang: Universitas Islam Negeri Walisongo 
Knapp \& Watkins. (2005). Genre Text, Grammar: Technologies for Teaching and Assessing Writing. Australia: University of New South Wales Press Ltd

Langan, J. (2010). College Writing Skill with Reading. Mc Grew Hill, a Division of the Mc Grew- Hill

Lestari, D. W. (2019). Developing Students' Writing Worksheet using Scientific Approach for the Tenth Grade Students. Medan: Universitas Negeri Medan

Namira, H. (2019). Developing Students' Worksheet Based on Scientific Approach in Listening Skill for Grade $X$ in SMK Negeri 10 Medan. Medan: Universitas Negeri Medan

Nation. (2001). Learning Vocabulary in another Language. New York: Cambridge University Press

Nation \& Webb. (2011). Researching and Analysing Vocabulary. Boston: Heinle Cengage Learning

Nunan, D. (2003). Practical English Language Teaching. Singapore: Mc Graw Hill Company

Pradita \& Sadiq (2016). Developing Student Vocabulary Worksheet by Using Affixes, 3: 1-16

Prastowo, A. (2011). Pengembangan Bahan Ajar Inovatif. Yogyakarta: Diva Press

Prastowo, A. (2014). Panduan Kreatif Membuat Bahan Ajar Inovatif. Yogyakarta: Diva Press

Richards, J. (2001). Approaches and Methods in Language Teaching. New York: Cambridge University Press

Sani, R.A. (2015). Pembelajaran Saintifik untuk Implementasi Kurikulum 2013. Jakarta: Bumi Aksara

Sarwanti. S (2016). Scientific Method in English Language Teaching, 12(1): 6075

Sugiyono. (2009). Metode Penelitian Kuantitatif, Kualitatif dan R\&D. Bandung : Alfabeta

Suharto, G. (2006). Pengukuran Penilaian Hasil Belajar Bahasa Inggris. Yogyakarta: P3B UNY

Supardi (2017). Student Worksheet Static Fluid Material Based on Scientific Approach Using Guided Inquiry Model, 2(1): 368-380 
Suparno, et al. (2017). Developing Students' Worksheets Applying Soft SkillBased Scientific Approach for Improving Building Engineering Students' Competencies in Vacational High Schools, 1-7

Triantoro. (2009). Mendesain Model Pembelajaran Inovatif Progresif. Surabaya: Kencana

Webb, S. (2005). Receptive and Productive Vocabulary Learning: The Effects of Reading and Writing on Word Knowledge. SSLA, 27: 33-52

Wyrick, J. (1987). Steps to Writing Well. New York: Rinehart and Winston. Inc.

Zinsser, W. (2006). On Writing Well: The Classic Guide to Writing Nonfiction. New York: Harper Collins

Zulyadaini (2017). Development of Student Worksheets Based Realistic Mathematics Education (RME), 13: 1-14 